\title{
Effects of Oiled Sediments on Mortality, Feeding and Growth of Winter Flounder Pseudopleuronectes americanus
}

\author{
G. L. Fletcher ${ }^{1}$, J. W. Kiceniuk ${ }^{2}$ and U. P. Williams ${ }^{2}$ \\ 1 Marine Sciences Research Laboratory, Memorial University of Newfoundland, St. John's, Newfoundland, Canada A1C 5S7 \\ ${ }^{2}$ Department of Fisheries and Oceans, P.O. Box 5667, St. John's, Newfoundland, Canada A1C 5S7
}

\begin{abstract}
Winter flounder were exposed to sediments contaminated with Venezuelan crude oil in 3 laboratory experiments of 4-5 months duration. Two of the experiments were conducted in summer during the flounder's feeding period and 1 during winter when they do not feed. Mortalities were observed in all experimental groups during summer, but were considerably greater in flounder exposed to oiled sediments than in those in un-oiled controls. Oiled sediments aged for a year remained toxic, although less so than freshly oiled sediments. No mortalities were observed during winter. Feeding rates were considerably reduced in flounder exposed to freshly oiled sediments. The aged oiled sediments had little or no effect on feeding rates. Control flounder showed greater increases in weight and condition than did exposed flounder, and flounder from aged oil revealed a greater increase in condition than did those exposed to fresh oil. Since winter flounder are obligatory residents of habitats which could become contaminated with oil, these results suggest that in the event of such an occurrence the winter flounder's ability to grow and store enough energy reserves to survive the winter could be reduced. It is suggested that the oil acts as a nonspecific stressor, which in conjunction with the high summer water temperatures and the effects of captivity resulted in significant mortality.
\end{abstract}

\section{INTRODUCTION}

Winter flounder Pseudopleuronectes americanus are found throughout the year in inshore areas of the east coast of North America (Leim and Scott, 1966). They generally inhabit soft muddy and sand-gravel bottoms at depths of $1-40 \mathrm{~m}$ and tolerate highly varying regimes of temperature, salinity and oxygen concentration (Klein-McPhee, 1978). The close proximity of the winter flounder's habitat to the shore makes them very susceptible to a wide variety of environmental contaminants of land, river and oceanic origin. In addition, their habit of burrowing into bottom sediments (Fletcher, 1975) and ingesting sediment material while feeding (Levings, 1972; Fletcher, unpublished) increases their exposure to contaminants which may not be a part of the water column. Therefore, since winter flounder are dependent on inshore areas for food supplies and spawning areas they may be unable to avoid exposure to environmental contamination.

A number of field studies have demonstrated that petroleum hydrocarbons may remain associated with marine sediments for years (Keizer et al., 1978; Mayo et al., 1978; Owens, 1978). Recently, Weber et al. (1979) found, in laboratory experiments, that juvenile English sole do not avoid oil contaminated sediments. McCain et al. (1978) have also demonstrated that this fish can accumulate petroleum hydrocarbons from experimentally oiled sediments. In addition their data suggest an enhanced weight loss and reduction in food intake by oil exposed flatfish.

In natural populations of Newfoundland winter flounder, growth during late summer and fall is largely confined to increases in condition with little or no increase in body length (Fletcher, unpublished data). The increase in condition during late summer is the result of the build up of necessary energy reserves to enable the fish to survive the winter non-feeding period, and in females, to complete the development of the ovaries (MacKinnon, 1972; Fletcher and King, 1978).

The present study was carried out to examine the toxicity of sediments contaminated with crude oil and their effect on feeding and growth of winter flounder during feeding (summer) and non feeding (winter) periods of the fish's annual life cycle. 


\section{MATERIALS AND METHODS}

Winter flounder Pseudopleuronectes americanus of length $25-40 \mathrm{~cm}$ were collected by SCUBA divers from Chapel's Cove, Conception Bay, Newfoundland (Fletcher, 1977). They were maintained in laboratory aquaria $(\sim 40,000 \mathrm{l})$ under ambient conditions of temperature and photoperiod, for 1 to 2 months before experimentation. Sand was obtained from the sea floor $(6-10 \mathrm{~m})$ at Chapel's Cove. The geochemistry of the sediments in the Chapel's Cove area is described in Slatt (1974). The sand was washed with seawater and dried at room temperature. Venezuelan crude oil was thoroughly mixed into the dried sand (1 l oil per approximately $45 \mathrm{~kg}$ sand). The sand, control or oiled $(45 \mathrm{~kg}$ ), was added to $300 \mathrm{l}$ aquaria to give a bottom layer of sand approximately $5 \mathrm{~cm}$ deep. The aquaria were supplied with air and running seawater (4-5 l $\mathrm{min}^{-1}$ ) at ambient conditions of temperature and photoperiod. Experiments were performed from August 7 to December 19, 1978, February 5 to June 25, 1979 and July 24 to November $7,1979$.

The experiments initiated in August 1978 and July 1979 were conducted in outdoor aquaria. The experiments initiated in February 1979 were carried out indoors. All experiments were conducted under ambient conditions of temperature and light. The outdoor aquaria were mounted in pairs, one tank approximately $60 \mathrm{~cm}$ above the other.

Two control (top and bottom) aquaria and 2 oiled sediment aquaria (top and bottom) were set up on July 31, 1978. They were supplied with water and air for $7 \mathrm{~d}$ before the flounder were added. All fish were weighed, measured and tagged for identification. Dead flounder were replaced by live fish up until August 21, 1978. Feeding was initiated on August 14. A measured amount of chopped whole capelin (less heads \& tails) was presented to each aquarium daily. Twenty-four hours following feeding, all remaining food was removed, weighed and the amount eaten by the flounder computed. Feeding was discontinued when most of the fish had ceased to eat (October 15, 1978). The experiment was terminated on December 19, 1978.

The sediments were removed from the aquaria during January 1979 and washed with seawater. These aged sediments were used to carry out the Febru-
ary-June experiments. No new oil was added to the oiled sediments. One control and 1 oiled sediment aquarium was set up and supplied with running seawater and air in mid January. Winter flounder were added to the aquaria on February 5, 1979 and maintained without food until June 26, 1979. These fish were not measured or tagged prior to the experiment. Following termination of these experiments, the sediments were again removed from the aquaria, washed and used in the July-October 1979 experiment.

On July 17, 1979, 3 pairs (top and bottom) of aquaria were set up; 2 contained control sediment, 2 sediment oiled on July 31, 1978 (old oil) and 2 freshly oiled sediment (July 17, 1979) (new oil). The aquaria were left for 1 week prior to the addition of the winter flounder. The flounder were added on July 24, 1979. These fish were not weighed or tagged prior to the experiment. The experimental fish were fed 3-4 times week ${ }^{-1}$. The experiment was terminated on November 7. 1979. Food consumption (g $100 \mathrm{~g}^{-1}$ body weight) was computed on the midpoint between the initial and final body weights in the August 1978 experiment and the final body weights in the August 1979 experiment.

Estimation of the concentrations of oil in the sediments were made by fluorescence spectroscopy (Hargrave and Phillips, 1975).

Condition factors were computed from the relation C. F. = Body weight $(\mathrm{g}) /$ length $(\mathrm{cm})^{3}$. Statistical comparisons between treatments were made using Student's t-test.

\section{RESULTS}

The changes in water temperature of the aquaria during the course of the experiments appear in Table 1. A thin film of oil could frequently by seen on the surface of water of the oiled sediment aquaria in 1978, spring 1979 and the 'new oil' experiments of summer 1979. An oil film was rarely seen in the old oil' experiments of 1979. Apart from the oil content, the oiled sediments did not appear to differ from the controls. A distinct odour of sulphide was associated with both of them.

The mean concentrations of oil $\left(\mu \mathrm{g} \mathrm{g}^{-1} \mathrm{dry}\right.$ sediment) in the sediments were as follows: August 10, 1978 , 4300; September 30, 1978, 2300; January 29, 1979,

Table 1. Mean water temperatures $\left({ }^{\circ} \mathrm{C}\right)$ during experiments, -; not measured

\begin{tabular}{|c|c|c|c|c|c|c|c|c|c|c|c|c|}
\hline \multirow{2}{*}{ Year } & \multicolumn{12}{|c|}{ Month } \\
\hline & $\mathrm{J}$ & F & $M$ & A & $M$ & $\mathrm{~J}$ & J & $\mathrm{A}$ & $\mathrm{S}$ & 0 & $N$ & $D$ \\
\hline 1978 & - & - & - & - & - & - & 8 & 14 & 11 & 8.6 & 5 & 2 \\
\hline 1979 & 1 & -0.5 & -0.5 & 1.1 & 2 & 6 & 11.6 & 13.7 & 12 & 8.4 & 6 & - \\
\hline
\end{tabular}


3060; July 5, 1979, 3200; November 7, 1979, old oil 2460; new oil 4500. Oil concentrations in control aquaria ranged from 20 to $60 \mu \mathrm{g} \mathrm{g}^{-1}$. No differences in oil concentrations were observed between the surface and deep sediments in the aquaria.

During the summer feeding periods most flounder were on the surface of the sand. However, in the fall, towards the end of the feeding period the flounder frequently buried in the sand with only their eyes showing. During the winter most were completely buried in the sediments throughout the experiments. There were no obvious differences between the floun-

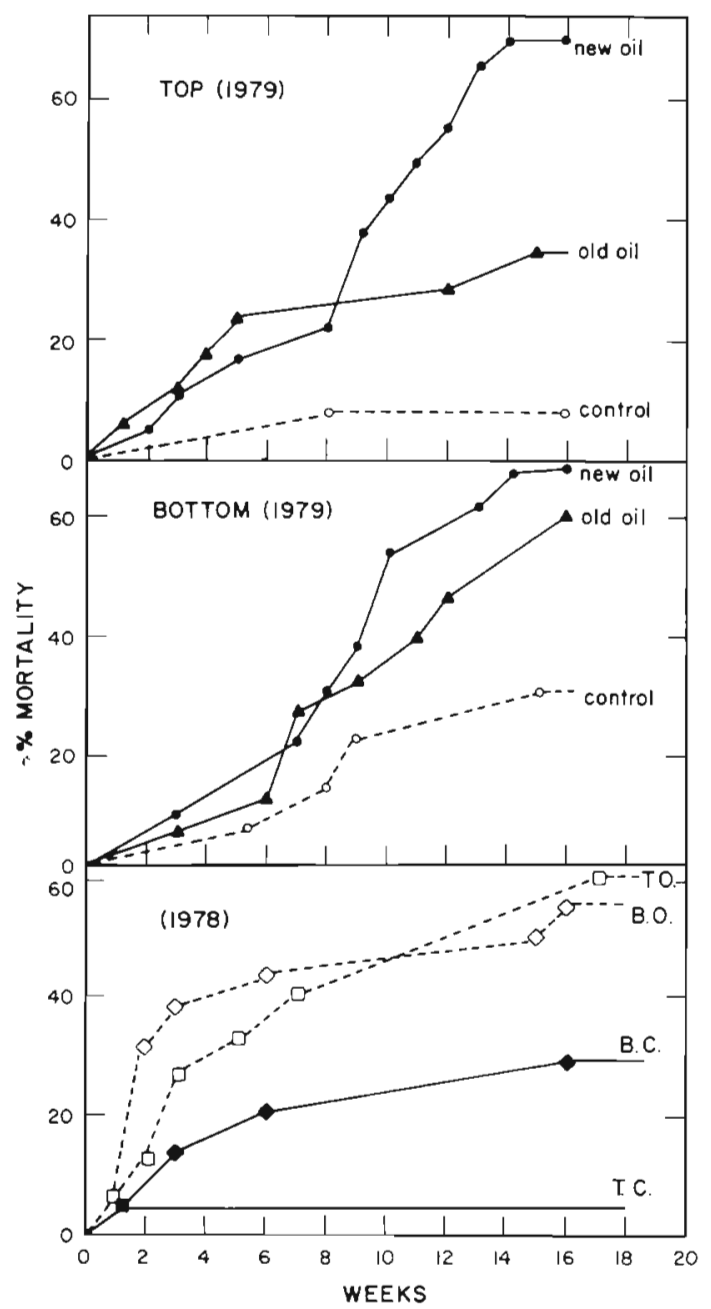

Fig. 1. Pseudopleuronectes americanus. Mortality of winter flounder exposed to control and oiled sand. TOP: aquaria mounted directly above BOTTOM aquaria. T.O.: Top aquarium, oiled sediments; B.O.: bottom aquarium, oiled sediments; T.C.: top aquarium, control sediments; B.C.: bottom aquarium, control sediments. Old oil: sediments coated with oil in 1978 and used in 1979 experiments. New oil: sediments coated with fresh oil immediately prior to 1979 experiments. Each aquarium contained between 13 and 18 fish at start of experiment der exposed to oil and control flounders with respect to burrowing behaviour.

\section{Mortality}

Mortalities were observed in all of the aquaria during the summer experiments of 1978 and 1979 (Fig. 1). These were considerably greater in the flounder exposed to the oiled sediments than in the controls. The data suggest that oiled sediments aged for a year ('old oil') were slightly less toxic than freshly oiled sediments. No mortalities were observed in the flounder exposed to oiled sediments during the winter months (February to June).

\section{Feeding}

Feeding was initiated on August 14, 1978 and July 25,1979 . However, the control fish, and occasionally one or more of the oil-exposed groups, ate all of the food presented to them, making it impossible to deter-

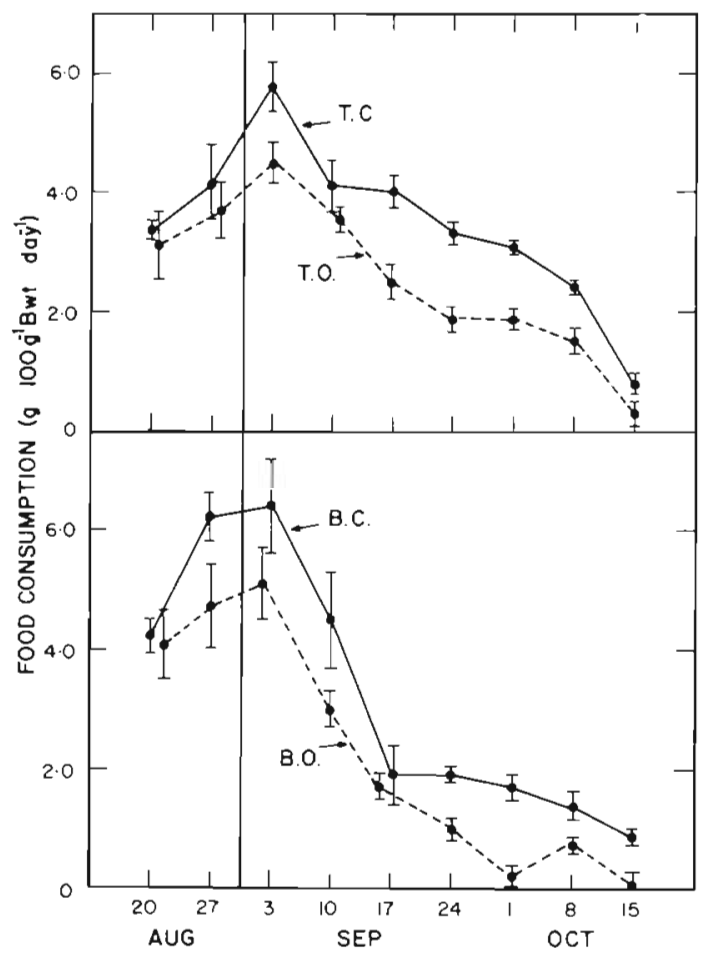

Fig. 2. Pseudopleuronectes americanus. Mean daily food consumption of winter flounder exposed to control and oiled sand. Values expressed as means \pm 1 standard error for 7 daily feedings. Vertical line between Aug. 27 and Sept. 3: fish received more food than they could eat in a day. T.C.: Top aquarium, control sediments; T.O.: top aquarium, oiled sediments; B.C.: bottom aquarium, control sediments; B.O.: bottom aquarium, oiled sediments 
Table 2. Pseudopleuronectes americanus. Food consumption and weight changes in control and oil-exposed winter flounder

\begin{tabular}{|c|c|c|c|}
\hline & $\begin{array}{l}\text { Total food } \\
\left(\mathrm{g} 100 \mathrm{~g}^{-1}\right. \\
\text { bodywt) }\end{array}$ & $\begin{array}{l}\text { consumed } \\
\text { ( } \% \text { of con- } \\
\text { trol values) }\end{array}$ & $\begin{array}{l}\text { Increase in } \\
\text { body wt }(\mathrm{g})\end{array}$ \\
\hline \multicolumn{4}{|c|}{1978 (Aug. 30-Oct. 16) } \\
\hline Top control & 165 & & $72.8 \pm 14.0(12)$ \\
\hline Top oil & 111 & 67.3 & $23.0 \pm 18.1(9)^{\circ}$ \\
\hline Bottom control & 136 & & $23.1 \pm 8.19(9)$ \\
\hline Bottom oil & 79.8 & 58.7 & $3.14 \pm 16.3(7)$ \\
\hline \multicolumn{4}{|c|}{1979 (Aug. 20.-Nov. 5) } \\
\hline Top control & 179 & & \\
\hline Top old oil & 163 & 91 & \\
\hline Top new oil & 88 & 49 & \\
\hline Bottom control & 169 & & \\
\hline Bottom old oil & 150 & 89 & \\
\hline Bottom new oil & 75 & 44 & \\
\hline \multicolumn{4}{|c|}{$\begin{array}{l}\text { - } \mathrm{P}<0.05 \text { compared with control values. Total food con- } \\
\text { sumption was obtained by summing daily intakes from } \\
\text { start of feeding-to-satiation to end of feeding period. Num- } \\
\text { bers in parenthesis indicate number of fish }\end{array}$} \\
\hline
\end{tabular}

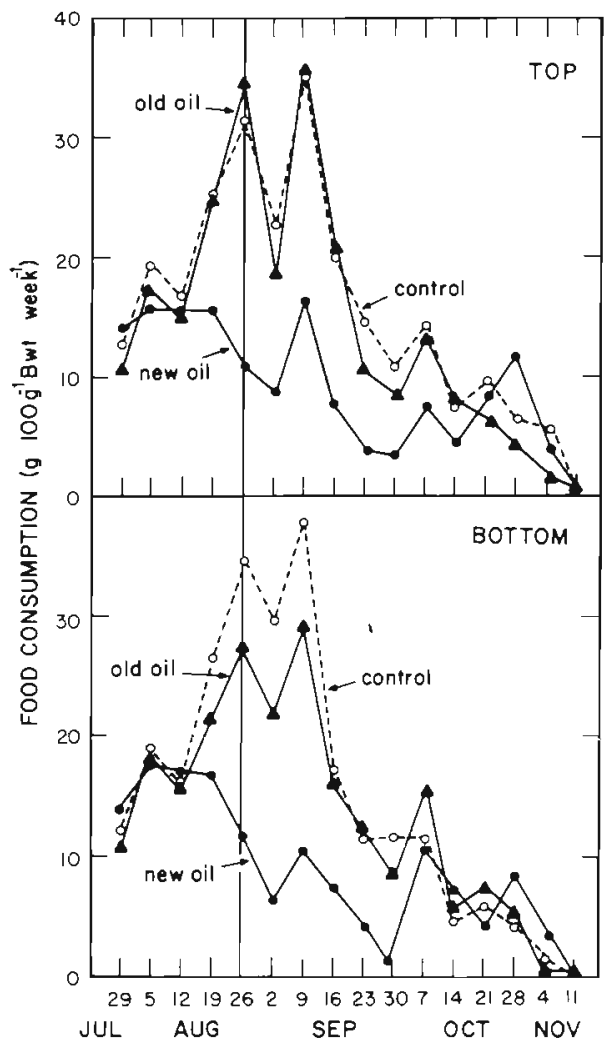

Fig. 3. Pseudopleuronectes americanus. Mean weekly food consumption of winter flounder exposed to control and oiled sand. Values expressed as means. Fish fed 3-4 times week ${ }^{-1}$. Vertical line on August 26: fish received more food than they could eat in a day. TOP: aquarium mounted immediately above BOTTOM aquarium mine the amount of food they were capable of eating. Therefore, the amount of food presented to each aquarium was increased until all of the groups left at least $10-20 \%$ uneaten after $24 \mathrm{~h}$. Food consumption from this time on (August 30, 1978, August 20, 1979) represents the amount the flounder ate when presented with an excess (i.e. when fed to satiation).

Feeding rates were highest during August and early September; they declined to near zero by October 15 , 1978 and November 5, 1979. In the 1978 experiments the feeding rates of the flounder in the upper (top) aquaria tended to be greater than in the lower aquaria. The flounder exposed to oil consistently ate less food than did the controls (Fig. 2). The total food consumed by the oil exposed group during the ad libitum feeding period was approximately $60 \%$ of that consumed by the control fish (Table 2, Fig. 4). In the 1979 feeding experiments, the flounder exposed to the aged oiled sediments ('old oil') ate only slightly less than the controls. However, the flounder exposed to the freshly oiled sediments ate considerably less than both the controls and the 'old oil' group (Fig. 3). The total food consumed by the oil-exposed groups during the ad libitum feeding period was approximately $90 \%$ ('old oil') and $45 \%$ ('new oil') of that consumed by the control fish (Table 2, Fig. 4).

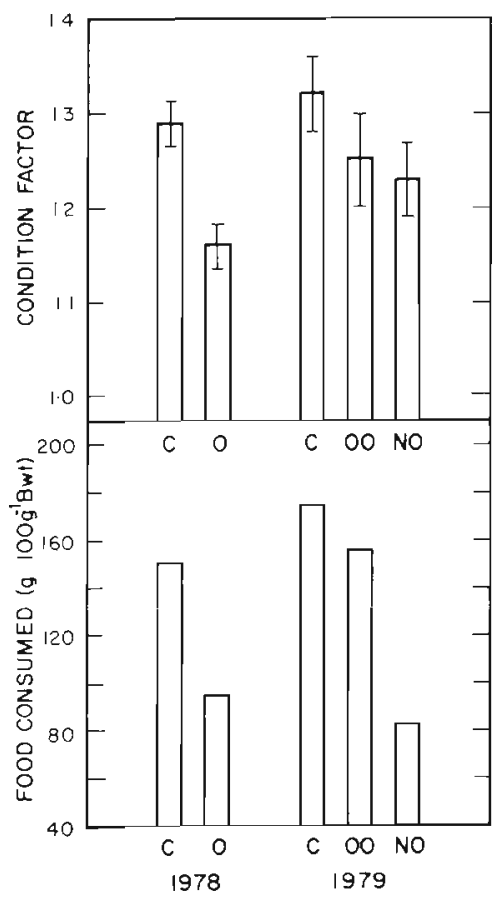

Fig. 4. Pseudopleuronectes americanus. Total food consumption and condition factors of winter flounder exposed to control and oiled sand. Data for replicate groups within each year were combined to give overall mean values. Condition factors expressed as means \pm one standard error. $\mathrm{C}$ : controls; $\mathrm{O}$ : oiltreated; OO: 'old oil'; NO: 'new oil 


\section{Growth and Condition}

In the 1978 feeding experiments all of the groups showed increases in body weight during the course of the experiment. The weight increases in the upper (top) aquaria groups were greater than those observed for the flounder in the lower (bottom) aquaria. Both of the control flounder groups (top \& bottom) showed greater increases in weight than did their respective oil exposed groups (Table 2). No significant changes occurred in the lengths of any of the experimental groups.

Condition factors increased in all but the bottom oil group of the 1978 experiments (Table 3). The greatest increase occurred in the top controls. Both of the control groups showed a greater increase in condition factor during the experiment than did their respective oil exposed group (Table 3, Fig. 4).

Initial body weights and lengths were not measured in the 1979 experiments, therefore comparisons between groups can only be made with respect to condition factors at the end of the experiment. Condition factors did not differ significantly between any of the oil exposed groups and their appropriate controls in any of the treatments. However, in both the top and bottom aquaria groups the mean final condition factor of the controls was greater than in the 'old oil' group which in turn was greater than the 'new oil' group (Table 3, Fig. 4).

\section{DISCUSSION}

Holmes et al. (1979) emphasized that petroleum may act as a nonspecific stressor. In their study they found that Mallard ducks could consume considerable quantities of petroleum without showing any obvious effects. However, when these birds were subjected to a mild cold stress in addition to the petroleum, a significant increase in the mortality occurred.

The lack of mortality in the flounder exposed to the oiled sediments during the winter months contrasts to the apparent relatively high toxicity of these sediments during the late summer and fall. Since winter flounder possess a number of physiological and behavioural attributes which enable them to exploit habitats characterized by low water temperatures successfully (Jeffries and Johnson, 1974; Fletcher, 1977; KleinMacPhee, 1978; van Guelpen and Davis, 1979), it may be that the summer water temperatures approach the incipient lethal level (Fry, 1971). If this is the case, then many of the factors which would be associated with captivity (confined space, shallow aquaria, air stones, feeding and removal of uneaten food) may act as stressors which, in conjunction with the seasonally high water temperatures, result in mortalities. It may be that during summer, captive winter flounder are in a very precarious physiological state which renders them unable to tolerate the additional stress of crude-oil exposure. The interrelationships between abiotic fac-

Table 3. Pseudopleuronectes americanus. Condition factors of control and oil-exposed winter flounder

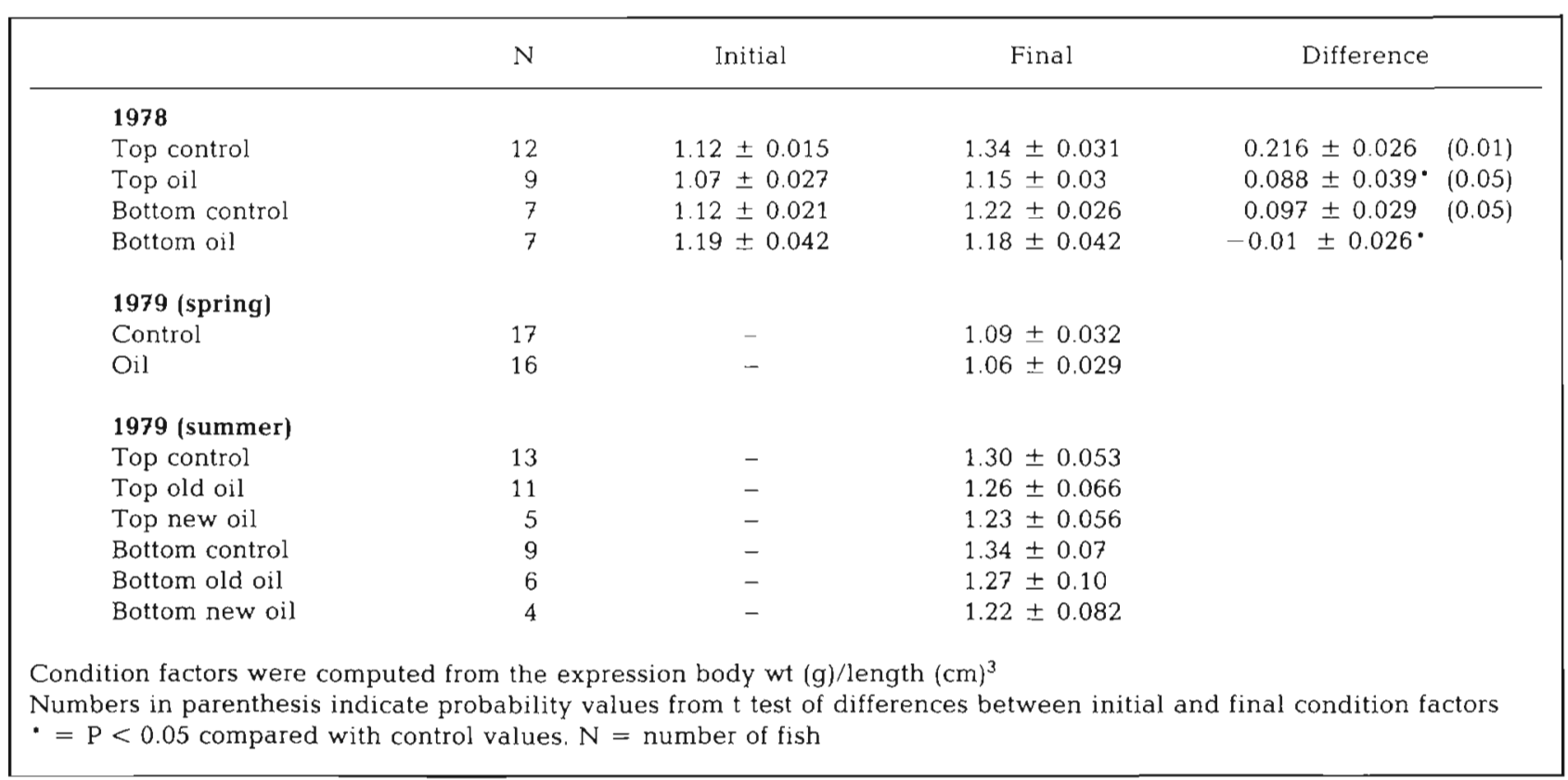


tors, such as temperature and salinity, and the toxicity of cadmium and various other toxicants has been discussed by Vernberg and Vernberg (1972) and Theede et al. (1979).

Despite the fact that the aged oil was lethal, it had little, if any, effect on the feeding rates. This lack of effect on feeding could reflect the reduced oil concentrations in these sediments, or a change in the composition of the oil (Ho and Karim, 1978; McCain et al. 1978; Roesijadi et al., 1978).

The 1978 feeding experiment clearly indicated that the oil-exposed flounder did not increase in weight or condition to the same degree as did the controls. This effect is probably a result of the reduced feeding rates of the oil-exposed group. In order to reduce the amount of stress, the 1979 groups were not tagged, therefore individual increases in weight and condition could not be computed. Nevertheless, the consistency in the results between the duplicate experimental groups with respect to food consumption and condition factors suggests that the oil-exposed groups did not increase in weight as much as did the controls. Since winter flounder are obliged to store energy prior to their winter non-feeding period, any reduction in feeding during the time when these reserves are being laid down could limit the flounder's ability to develop gonads and survive the winter.

Acknowledgements. This research was supported in part by Natural Sciences \& Engineering Research Council of Canada, Grant No. A6836. This is Marine Sciences Research Laboratory Contribution Number 399.

\section{LITERATURE CITED}

Fletcher, G. L. (1975). The effects of capture 'stress' and storage of whole blood on the red blood cells, plasma proteins, glucose and electrolytes of the winter flounder (Pseudopleuronectes americanus). Can. J. Zool. 53: 197-206

Fletcher, G. L. (1977). Circannual cycles of blood plasma freezing point and $\mathrm{Na}^{+}$and $\mathrm{Cl}^{-}$concentrations in Newfoundland winter flounder (Pseudopleuronectes americanus): correlation with water temperature and photoperiod. Can. J. Zool. 55: 789-795

Fletcher, G. L., King, M. J. (1978). Seasonal dynamics of $\mathrm{Cu}^{2+}$, $\mathrm{Zn}^{2+}, \mathrm{Ca}^{2+}$, and $\mathrm{Mg}^{2+}$ in gonads and liver of winter flounder (Pseudopleuronectes americanus): evidence for summer storage of $\mathrm{Zn}^{2+}$ for winter gonad development in females. Can. J. Zool. 56: 284-290

Fry, F. E. J. (1971). The effect of environmental factors on the physiology of fish. In: Hoar, W. S., Randall, D. J. (eds) Fish physiology, Vol. 6. Academic Press, New York, pp. 1-98

Hargrave, B. T., Phillips, G. A. (1975). Estimates of oil in aquatic sediments by fluorescence spectroscopy. Environ. Pollut. 8: 193-215

Ho, C. L., Karim, H. (1978). Impact of adsorbed petroleum hydrocarbons on marine organisms. Mar. Pollut. Bull. 9 $156-162$

Holmes, W. N., Gorsline, J., Cronshaw, J. (1979). Effects of mild cold stress on the survival of seawater-adapted Mallard ducks (Anas platyrhynchas) maintained on food contaminated with petroleum. Environ. Res. 20: 425-444

Jeffries, H. P., Johnson, W. C. (1974). Seasonal distributions of bottom fishes in the Narragansett Bay Area: Seven year variations in the abundance of winter flounder (Pseudopleuronectes americanus). J. Fish. Res. Bd Can. 31: $1057-1066$

Keizer, P. D., Ahern, T. P., Dale, J., Vandermeulen, J. H. (1978). Residues of Bunker C oil in Chedabucto Bay, Nova Scotia, 6 years after the Arrow spill. J. Fish. Res. Bd Can. 35: 528-535

Klein-MacPhee, G. (1978). Synopsis of biological data for the winter flounder, Pseudopleuronectes americanus (Walbaum). NOAA Technical Report NMFS Circ. 414: 1-43

Leim, A. H., Scott, W. B. (1966). Fishes of the Atlantic coast of Canada. Bull. Fish. Res. Bd Can. 155

Levings, C. D. (1972). A study of temporal change in a marine benthic community, with particular reference to predation by Pseudopleuronectes americanus (Walbaum) (Pisces: Pleuronectidae). Ph. D. thesis, Dalhousie University, Halifax, Nova Scotia, Canada

MacKinnon, J. C. (1972). Summer storage of energy and its use for winter metabolism and gonad maturation in American plaice (Hippoglossoides platessoides). J. Fish. Res. Bd Can. 29: 1749-1759

Mayo, D. W., Page, D. S., Cooley, J., Sorenson, E., Bradley, F., Gilfillan, E. S., Hanson, S. A. (1978). Weathering characteristics of petroleum hydrocarbons deposited in fine clay marine sediments, Searsport, Maine. J. Fish. Res. Bd Can. 35: $552-562$

McCain, B. B., Hodgkins, H. O., Gronlund, W. D., Hawkes, J. W., Brown, D. W., Meyers, M. S., Vandermeulen, J. H. (1978). Bioavailability of crude oil from experimentally oiled sediments to English sole (Parophrys vetulus), and pathological consequences. J. Fish. Res. Bd Can. 35: $657-664$

Owens, E. H. (1978). Mechanical dispersal of oil stranded in the littoral zone. J. Fish. Res. Bd Can. 35: 563-572

Roesijadi, G., Woodruff, D. L., Anderson, J. W (1978). Bioavailability of naphthalenes from marine sediments artifically contaminated with Prudhoe Bay crude oil. Environ. Pollut. 15: 223-229

Slatt, R. M. (1974). Geochemistry of bottom sediments, Conception Bay, Southeastern Newfoundland. Can. J. Earth Sci. 11. 768-784

Theede, H., Scholy, N., Fischer, H. (1979). Temperature and salinity effects on the acute toxicity of cadmium to Laomedea loveni (Hydrozoa). Mar Ecol. Prog. Ser 1: $13-19$

Van Guelpen, L., Davis, C. C. (1979). Seasonal movements of the winter flounder (Pseudopleuronectes americanus) in two contrasting inshore locations in Newfoundland. Trans. Am. Fish. Soc. 108: 26-37

Vernberg, W. B., Vernberg, F. J. (1972). Environmental physiology of marine animals, Springer-Verlag, New York

Weber, D., Gronlund, W., Scherman, T., Brown, D. (1979). Non-avoidance of oil-contaminated sediment by juvenle English sole (Paraphrys vetulus). In: Calabrese, A., Thurburg, F. P. (eds) Proceedings of the symposium on pollution and physiology of marine organisms. Milford, Connecticut, USA. 